\title{
Review of the circulation and characteristics of intermediate water masses of the Mediterranean--implications for cold-water coral habitats
}

\author{
Daniel R. Hayes
}

Oceanography Center, University of Cyprus, dhayes@ucy.ac.cy, +357 99928955

\section{Pierre-Marie Poulain}

Istituto Nazionale di Oceanografia e di Geofisica Sperimentale, Trieste, Italy, ppoulain@inogs.it, +390402140322

\section{Pierre Testor}

CNRS-Sorbonne Universités (UPMC Univ. Pierre et Marie Curie, Paris 06), Paris, France, testor@1ocean-ipsl.upmc.fr

\section{Laurent Mortier}

CNRS-Sorbonne Universités (UPMC Univ. Pierre et Marie Curie, Paris 06), Paris, France, mortier@locean-ipsl.upmc.fr

\section{Anthony Bosse}

Geophysical Institute, University of Bergen and Bjerknes Center for Climate Research, Bergen, Norway, anthony.bosse@uib.no, +47 55582626

\section{Xavier du Madron}

CEFREM, Perpignan, France, demadron@,univ-perp.fr, +33468662248 
Abstract This chapter describes the main features of the circulation and properties of the intermediate water masses of the Mediterranean. Interaction with other water masses is also briefly summarized. Both observational and numerical studies described in the literature are used, as well as some more recent, unpublished data sets. It is shown that the main water mass important to coldwater coral habitats is the Levantine Intermediate Water (LIW) which forms in the Levantine Sea, Eastern Mediterranean and spreads throughout the entire Mediterranean before leaving via the Gibraltar Strait. This pathway is described as well as the expected temperature, salinity, dissolved oxygen and relative nutrient loads at existing known habitats. Current speed regimes are estimated from the few studies that exist.

\section{Key Words}

Mediterranean Sea, Hydrography, circulation, intermediate water, deep water

\section{Objective}

In this paper, the current understanding of the flow and characteristics of intermediate Mediterranean Sea water masses is described. Particular emphasis is given to selected regions where cold water corals (CWC) have been discovered. Taviani et al. (2011) (and references therein) identified five discrete provinces: the Southwestern Adriatic, the Northern Ionian, the Sicily Channel, the Alboran Sea, and the Catalan-Provençal-Ligurian canyons, and more recently the Nora canyon, offshore Sardinia. Live CWCs have also been found in other places such as polyps of deep-sea scleractinian corals on the top of the Eratosthenes Seamount (Galil and Zibrowius 1998), and on the Anaximenes ridge summit south of Turkey, black Antipathes coral and occasional Desmophyllum corals were observed (Raineault et al. 2013). Epibenthic communities on the Anaxagoras seamount hosted cold water octocorals and scleractinian corals (Shank et al. 2011). There is new evidence of CWC communities in the Cassidaigne Canyon on the Provençal east of the Gulf of Lion between Marseille and Toulon at depths of the intermediate water (around $500 \mathrm{~m}$ ) (Fabri et al. 2017). (also see ??? this volume for a more detailed description of the distribution of (WC). Particular emphasis will be given to flow and water properties at the depths at which CWC are known to thrive: $350-600 \mathrm{~m}$ (Taviani et al. 2011), which corresponds to intermediate water masses. A map of the regions where these ocean depths are found is shown in Fig. 1, along with the confirmed CWC discoveries above.

Deep water masses will also be briefly described since they are directly linked to the intermediate water through mixing and uplift. Near-surface layers are also briefly described since they influence the production and volume flux of the intermediate water masses. Also, in certain places, during dense water formation events, the seafloor may have direct contact with the surface layer, and later 
indirectly through the lateral spreading or downward cascading of these newlyformed waters.

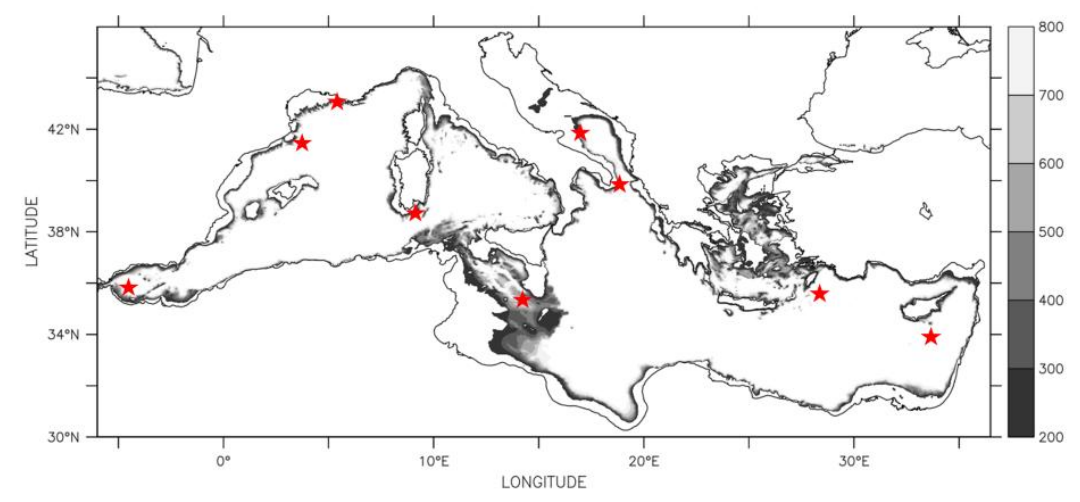

Fig. 1. Mediterranean basin and depths at which cold water corals may be found (dark grey). Stars indicate known locations of living cold-water corals. Source of bathymetry is EMODnet (2017).

By far, the dominant water mass at depths between 350 and $600 \mathrm{~m}$ is the Levantine Intermediate Water (LIW). In fact, it is the most voluminous water mass produced in the Mediterranean (Skliris 2014; Lascaratos 1993). LIW is found throughout the Mediterranean, not just the Levantine region in which it forms. See Fig. 2. Other intermediate water masses include the Western Intermediate Water (WIW) formed by wintertime cooling of Atlantic Water in the Western Mediterranean and the Cretan Intermediate Water (CIW) formed in winter time and mostly trapped in the Aegean Sea. These two intermediate water are produced in much lower quantities and their pathways are not easily identified (Millot and Taupier-Letage 2005). However, it has been shown by Millot (2013) that the Aegean/Cretan waters contribute significantly to what some call the LIW in the western basin, so the name Eastern Intermediate Water (EIW) was suggested. After a description of the approach taken, the paper presents processes related to the spotty, intermittent intermediate water mass formation and transformation. The identifying characteristics, pathways and flow speeds of the LIW are discussed in the final part of the paper, in subsections for the Eastern and Western Mediterranean, respectively. Particular attention will be given to confirmed discoveries of CWC as well as sites that have a high level of interest (like seamounts and canyons). 

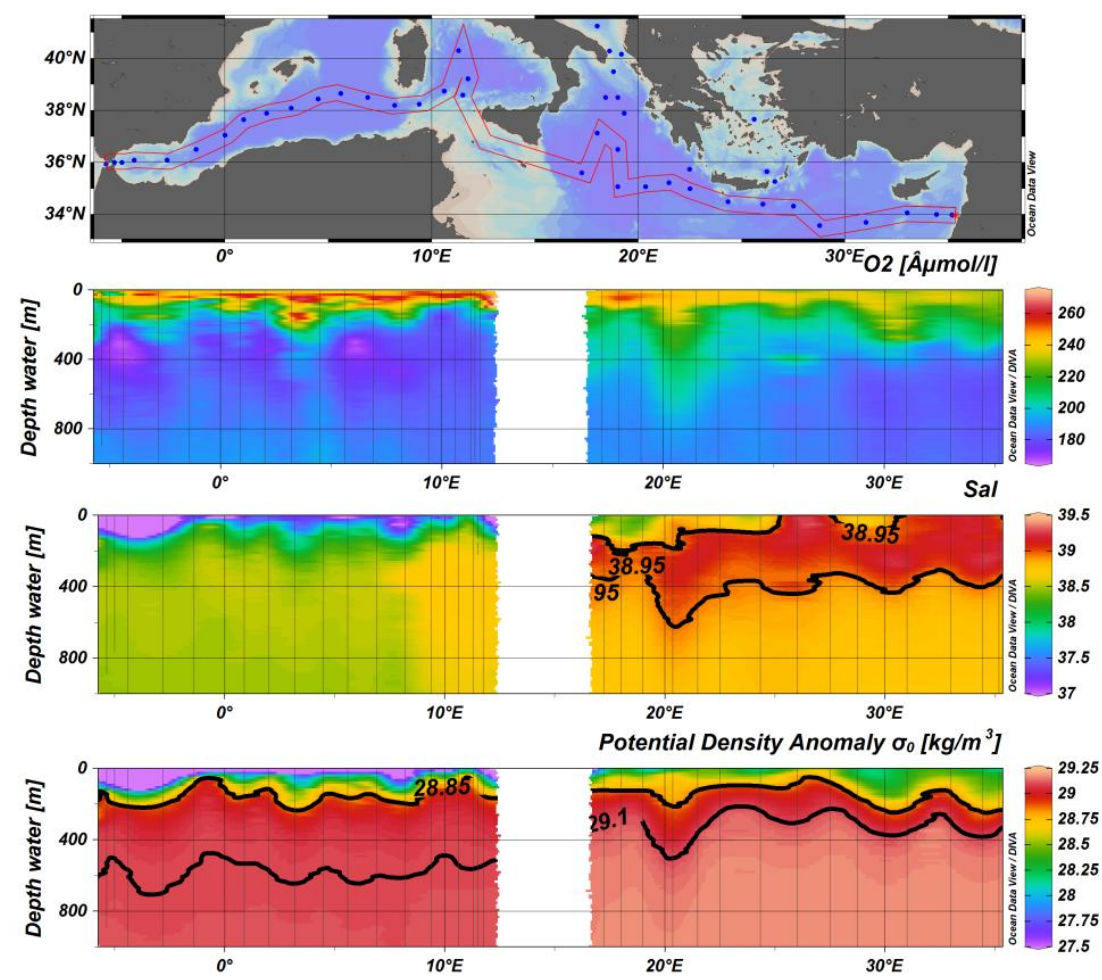

Fig. 2. Levantine Intermediate Water spreading from East to West (indicated by potential density anomaly between 28.85 and $29.1 \mathrm{~kg} \mathrm{~m}^{-3}$ ). (data plotted from Tanhua 2012)

\section{Scope}

This study focuses on the current understanding of the present-day characteristics and circulation, water mass pathways and currents of the Mediterranean below the surface layer and above the deep layer. Because of the large spatial and temporal gaps in the observational data sets available, in particular for subsurface layers, this understanding is based on a variety of sources. Firstly, historical observations, going back to the early to mid $20^{\text {th }}$ century provide a low resolution set of static views. Naturally, changes have occurred over this time period, many of them probably not known to us because of the sparseness of the observations. In order to piece together a coherent structure, however, we must glean the essential information from these data sets and make conclusions about what is a reasonable mean state.

Newer, unpublished, data sets certainly exist, and a few examples related to the authors' work are presented below. In general, these include CTD cruises, 
eXpendable BathyThermographs (XBTs), profiling floats, gliders and a few fixed point stations. These platforms measure temperature, conductivity (except XBT), and pressure. In many cases, dissolved oxygen is also measured, but chlorophyll, nutrient, and inorganic carbon data are sparse. Very few platforms measure properties below $1000 \mathrm{~m}$, and even fewer measure currents directly (at any depth), making characterization of deep flows extremely difficult. For this reason, currents are usually estimated using the assumption of geostrophic balance, which is wrought with pitfalls in the Mediterranean, in particular because of an unknown reference at the typical maximum observation depth. It should be noted that satellite altimetry (dynamic height and Sea Level Anomaly: SLA) can also aid in calculating ocean currents in a depth-averaged (barotropic) sense, but the intermediate flow may not coincide because of stratification (baroclinic flows). In some regions, these complementary observation platforms have been organized into observatories which operate for extended periods, often providing near realtime information, and associated prediction and assimilation products. For example, the MOOSE in France captured processes related to deep and intermediate water formation, as in Houpert et al. (2016) and Bosse et al. (2016). Where relevant, these have been identified as a potential source of information that could be analyzed further to enhance the present, primarily retrospective, study.

One exception to the lack of observable changes is the striking example of the shift in the formation of the EMDW, from the 90s to today and later the WMDW, both of which indirectly affect the overlying intermediate water properties (see Schroeder in this volume). Another example of observed change is the ongoing change in salinity of the Mediterranean (see Skliris in this volume). Despite these exceptions, most observational data sets are inadequate to describe the spatial or temporal variations, especially in the intermediate layer which is expected (and sometimes observed) to be tremendously complex. Surface layer variability is likely even more complex, but remote sensing and surface drifting platforms have provided a realistic glimpse (Rio et al. 2014; Poulain et al. 2012; Menna et al. 2012).

For these reasons, a second source of information is often used: numerical models and their associated re-analysis data sets. While theoretical considerations and hydrodynamic simulations of varying complexity help in understanding the important processes of intermediate water mass transformation and spreading, and can even provide accurate estimates of water mass production rates and exchanges through straits, they are notoriously bad at prediction or reconstruction of the true ocean state. Nevertheless, through the merging of observational data sets with dynamic formalisms (data assimilation), realistic ocean state estimates can be made and are examined here in addition to published and ongoing observational studies (see Sofianos in this volume) and a thorough review of the Mediterranean structure and dynamics from a 20-year reanalysis from Pinardi et al. (2015).

In this chapter, the current steady-state view emerging from the literature is described, while acknowledging that this is a gross simplification, constantly violated by the rapid transients and long-term changes mentioned above. Despite 
these violations, the steady-state view is useful as a starting point upon which to base a detailed discussion of cross-basin interactions and to understand the relevant processes and likely ways that said transients spread around the basin.

A summary of what is known about the water formation processes is provided in the following sub-sections, while the resulting spreading and pathways are discussed in the following section.

\section{Formation of Mediterranean water masses}

The Mediterranean Sea functions like the global ocean in that it hosts overturning circulation renewing waters however within shorter timescale of a century or less. There are three such cells: a pan-Mediterranean one, an Eastern Mediterranean one, and a Western Mediterranean one (the latter two separated by the Sicily Channel with a sill depth of about $500 \mathrm{~m}$ ). The uppermost one is open and brings Atlantic Water (AW: $\left.15^{\circ} \mathrm{C}, 36.2\right)$ in through the Straits of Gibraltar (sill depth of about $300 \mathrm{~m}$ ) to make up for the net evaporative losses of the basin. Other masses not formed in the basin include the Black Sea Water and river input. These are restricted to the surface and are not directly relevant to CWC. They do, however, have an effect on the formation of the deeper water masses. Intermediate water with properties of approximately $\left(13.5^{\circ} \mathrm{C}, 38.4\right)$ also exits Gibraltar in a bottom layer (Tsimplis and Bryden 2000). The incoming AW is modified by mixing and air-sea fluxes as it traverses the basin, and some of it leaves the surface layer through densification in both east and west "closed" overturning cells (relatively cold, salty water sinks in sporadic events at particular locations to particular depths). The displaced deeper waters upwell in much broader, slower processes over each basin, then mix with intermediate waters that have formed through less intense densification, which traverse back to the west in complicated ways. Finally, the uppermost part of this intermediate layer, a form of the Levantine Intermediate Water (LIW), exits the Mediterranean in the bottom layer at Gibraltar. An excellent summary of the above with references is provided by Malanotte-Rizzoli et al. (2014) as well as Tsimplis et al. (2006). A schematic is shown in Fig. 3. A summary of Mediterranean deep and intermediate water formation is provided next. 


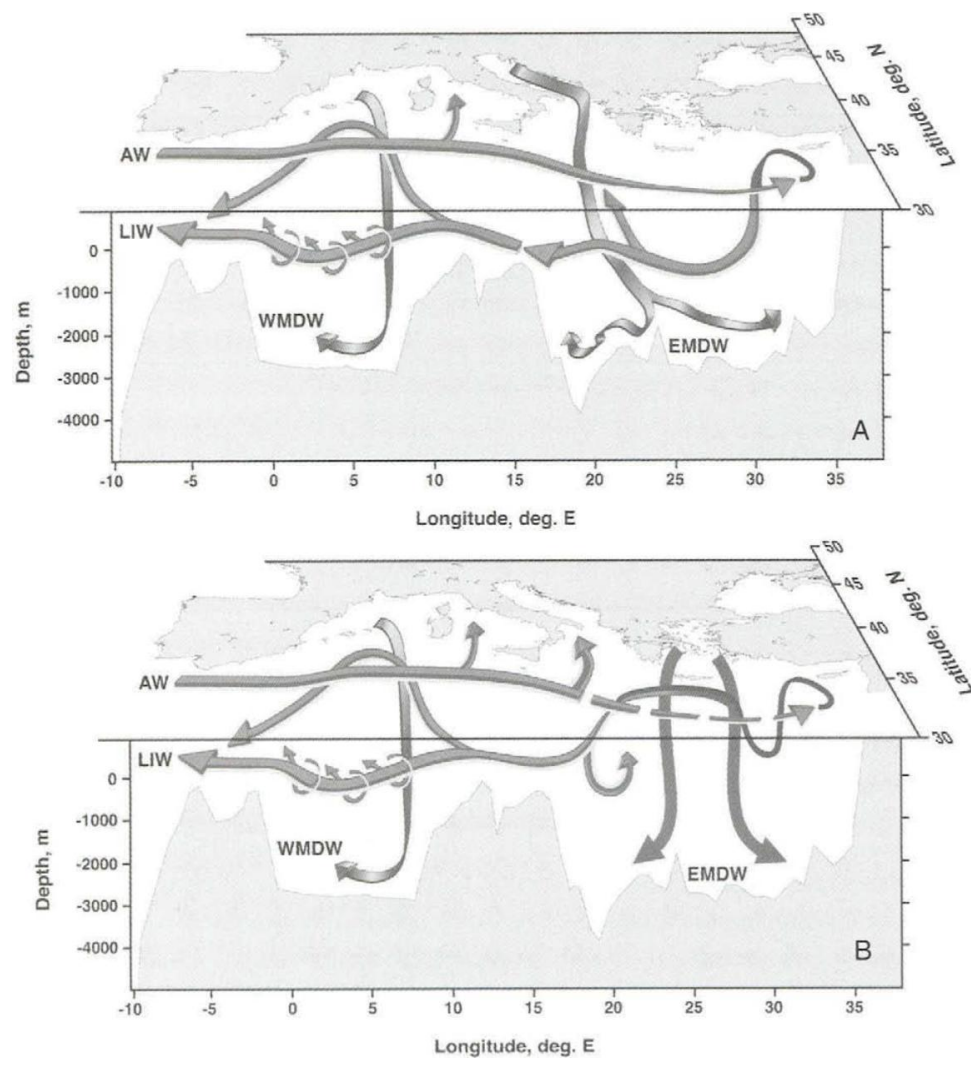

Fig. 3. The thermohaline of the Mediterranean in the time before (top) and during (bottom) the Eastern Mediterranean Transient (source: Tsimplis et al. 2006) [redraw].

\section{Deep water formation}

The formation of deep water is briefly summarized here in order to understand the intermediate water properties and pathways. There are two main types of deep water in the Mediterranean: Western Mediterranean Deep Water (WMDW) and Eastern Mediterranean Deep Water (EMDW). Each water mass accumulates at depths much greater than the sill depths separating the basins from each other and the Atlantic. The water masses spread along the bottom, mixing with the surroundings which modifies the deep layers.

WMDW forms in the Gulf of Lions nearly every February-March after intense surface buoyancy loss (evaporation and cooling via latent and sensible means) is applied to pre-conditioned waters in the open sea. Strong, destabilizing buoyancy loss occurs during occasions with high winds, which also mix the surface layer mechanically. If the surface fluxes are strong, frequent and/or long enough for the 
given water column properties, WMDW is produced. If not, an intermediate water mass is produced: Western Intermediate Water (WIW). WIW is slightly cooler and fresher than the LIW that arrives from the Eastern Mediterranean. The presence of AW with salinity higher than normal near the surface and the underlying LIW contributes to more efficient production of these two types of water, as less buoyancy loss is required to produce a denser water mass. Therefore, as the AW and LIW properties vary, the volume and density of the water mass formed varies interannually. In recent years WMDW has become progressively warmer and saltier (Schroeder et al. 2010; Houpert et al. 2016). Some years the ocean bottom is reached (about $2400 \mathrm{~m}$ ) and some years lesser depths are reached (about $1500 \mathrm{~m}$ ). Dense water production on the shelf can also result in cascading dense water plumes reaching depths from 200 to $2000 \mathrm{~m}$ or more (Canals et al. 2006; Durrieu de Madron et al. 2005, 2013).

EMDW forms either in the southern Adriatic Sea (Fig. 3a) or the Aegean Sea (Fig. 3b). Evidence points to decadal variability of a "precarious balance" in the source location of EMDW (Roether et al. 2007). In 1989, deep and intermediate water from the Cretan Sea (CDW and CIW) were dense enough to sink to the depths of the Levantine for the first time (Theocharis et al. 1999). Before that, CDW left the Cretan Sea and settled to depths below the LIW, but above EMDW of Adriatic origin. The formation of EMDW in the Adriatic is influenced by the LIW properties and the dense shelf water of the northern Adriatic that cascades along the west coast to mix with the LIW in the South Adriatic cyclonic gyre. This Adriatic Deep Water (ADW) spreads into the depths of the Ionian and Levantine Seas. In the years from 1989 until 1992, the Cretan Sea dominated the formation of EMDW, and this may be explained by an oscillation of the Ionian Circulation which feeds more or less LIW into the southern Adriatic (Borzelli et al. 2009; Gačić et al. 2010; 2011). Harsh weather conditions in the northern Adriatic can trigger the formation and spreading of extremely dense EMDW. See Bensi et al. (2013) for an example in 2012. For more details, see Schroeder (in this volume). In all cases of deep water formation, the presence and properties of LIW play a critical part (Wu and Haines 1996; Skliris and Lascaratos 2004).

\section{LIW formation}

Levantine Intermediate Water (LIW) is usually defined in the Eastern Mediterranean by a potential density anomaly $\sigma_{\theta}$ of 28.85 to $29.10 \mathrm{~kg} \mathrm{~m}^{-3}$ (temperature of 15 to $16^{\circ} \mathrm{C}$ and salinity 38.95 to 39.05 ). Taken together, historical studies (Table 1 of Lascaratos et al. 1993) show wider ranges (28.85-29.15, 14.6$16.4^{\circ} \mathrm{C}, 38.85-39.15$,). LIW resides primarily at depths between $150 \mathrm{~m}$ and $400 \mathrm{~m}$ (Lascaratos et al. 1993), although naturally it is found at and near the surface in regions in which it is formed and descends as it spreads to other regions. It has been seen as deep as $500 \mathrm{~m}$ at the base of the anticyclonic Cyprus Eddy (Hayes et al. 2016a). It can be seen as a layer of salinity maximum in those depths 
throughout the entire Mediterranean, although of different absolute salinity and temperature because of mixing during its spread away from the formation region.

This water mass most likely forms in the Rhodes Gyre (Nielsen 1912; Lacombe and Tchernia 1960; Wüst 1961; Ovchinnikov 1984; Lascaratos and Nittis 1998), although many authors have suggested other locations (Southern Levantine: Morcos 1972; anticyclonic eddies: Brenner et al. 1991; Northern Levantine: Sur et al. 1992; LIWEX Group 2003). Unfortunately, observations are insufficient to support claims as to the dominance and persistence of the various sources. Rare, direct observations were described in LIWEX Group (2003) when in fact deep water formation was observed in the Rhodes Gyre (LDW). In that study, LIW was formed by simple cooling and evaporation of the surface mixed layer, which deepened gradually to $100 \mathrm{~m}$. Since direct observations are scarce, various numerical and reanalysis studies have been carried out. In numerical simulations (Lascaratos and Nittis 1998; Nittis and Lascaratos 1998), mixing to $400 \mathrm{~m}$ was simulated in the Rhodes Gyre, favored because the upward-doming isopycnals of the cyclonic gyre reduced the surface density and intermediate stability of the water column underlying the mixed layer. This is believed to be the primary mechanism for LIW formation. A short summary of the above can also be found in Schroeder et al. (2012).

\section{Water mass characteristics and flows}

\section{Eastern Mediterranean}

Various mechanisms and locations may generate LIW in the Eastern Mediterranean in winter, which then spreads throughout the basin, eventually leaving through the Sicily Channel, possibly after one or more circuits in the basin. The sill depth at the Sicily Channel is just over $500 \mathrm{~m}$, but only $35 \mathrm{~km}$ wide below $200 \mathrm{~m}$. The manner in which this water moves through the basin is not well-observed, with most of the available observations sparsely distributed in time and space. These have been supplemented by and compared with numerical simulations, and have been incorporated in re-analyses (models that assimilate historical data). Certain points will be established below as follows. After formation, lateral (isopycnal) spreading and mixing occur, modifying the initial T$\mathrm{S}$ properties. Both mean flow and eddies transport LIW throughout the eastern basin. In some cases, LIW is a distinct, homogeneous layer (thermostad in the core of an eddy), but in other cases it is not, and even both can exist at the same time.

While there are a few early hydrographic studies related to the formation of deep and intermediate water (see above), they do not reveal much information on the dispersion pathways because they do not cover large regions synoptically, nor with statistical significance. The intermediate circulation in the Eastern 
Mediterranean was first estimated by Ovchinnikov (1966). Based on hydrographic cruises, he concluded that the intermediate circulation is a less-intense version of the surface circulation (which cannot be true everywhere and at least not at Sicily and Gibraltar Straits or there would be no balance with the surface Atlantic Water inflow). Gerges (1977) uses a diagnostic model to conclude the intermediate layers of the Levantine move cyclonically around the basin, as was believed to be the case near the surface. In that same study, another cyclonic gyre is illustrated in the Ionian, while there is a weak exchange at the Sicily Channel. MalanotteRizzoli and Hecht (1988) summarize the state of knowledge before mesoscale effects were sufficiently observed, out of necessity. Of note is the study of Wüst (1961) showing LIW flowing westwards from the formation region (Rhodes Gyre) and mixing with layers above/below. Other studies show that the salinity maximum is distinct enough to be observed in the Ionian, the Adriatic, and parts of the Western Mediterranean with a core value of 38.9 at the Cretan Passage and 38.7 at the Sicily Channel (Malanotte-Rizzoli and Hecht 1988). The dispersion of LIW in the Levantine was described in detail for the first time as part of an Israeli cruise program called Marine Climate in the period 1979-84 (Hecht et al. 1988), with the new picture emerging that LIW spatial distribution in the Levantine was correlated with mesoscale variability, with LIW often trapped inside anticyclonic eddies. Scales of features resolved were $60-100 \mathrm{~km}$. The fact that mesoscale variability dominated the spreading of LIW within the entire eastern basin was revealed by the POEM cruises as described by Özsoy et al. $(1989,1991)$. Ozturgut (1976) and Ovchinnikov (1984) also link LIW formation to mesoscale processes, which prove to be a critical aspect of the Eastern Mediterranean.

Based on POEM cruises in March of 1989 , pockets of deep, $15^{\circ} \mathrm{C}$ isotherms $(500 \mathrm{~m})$ were shown away from the Rhodes Gyre in Özsoy. et al., (1993), while near the center of the gyre, very shallow depths were observed $(10 \mathrm{~m})$. These pockets were associated with anticyclonic eddies containing LIW. From 1985 to 1990, dynamic height maps for each POEM cruise at 300 dbar relative to 800 dbar showed long-lived (months to years) anticyclonic eddies intermingled with a weaker cyclonic circulation of the Rhodes Gyre.

The LIWEX Group (2003), who found that subsequent to Levantine deep and intermediate water mass formation in the Rhodes Gyre and northern Levantine (respectively), LIW subducts under the low density layers of the surface and spreads along isopycnal surfaces. Based on grids of temperature, salinity, and oxygen profiles, it is claimed that one pathway is to the west, into the Aegean and Cretan Seas, with some of the LIW continuing around the cyclonic gyre, heading back east after passing Crete. A second pathway is directly south from the formation region, opposing the cyclonic flow of the gyre, and possibly entering an open sea eddy (Fig. 4). Attempts to synthesize available hydrographic observations to estimate LIW pathways were made by Millot and Taupier-Letage (2005), who show only a few indicative arrows in the Eastern Mediterranean. The only suggested direct paths of LIW are the ones from the main formation area in the Rhodes Gyre towards the west along the northern edges of the Cretan Passage and Ionian Seas (Millot and Taupier-Letage 2005). The other pathways of LIW 
mentioned in Millot and Taupier-Letage (2005) are the possible entrainment into wind-induced eddies along the northern coast (Ierapetra and Pelops), the entry of some LIW into the southern Adriatic, and the possible recirculation at the Sicily Channel.

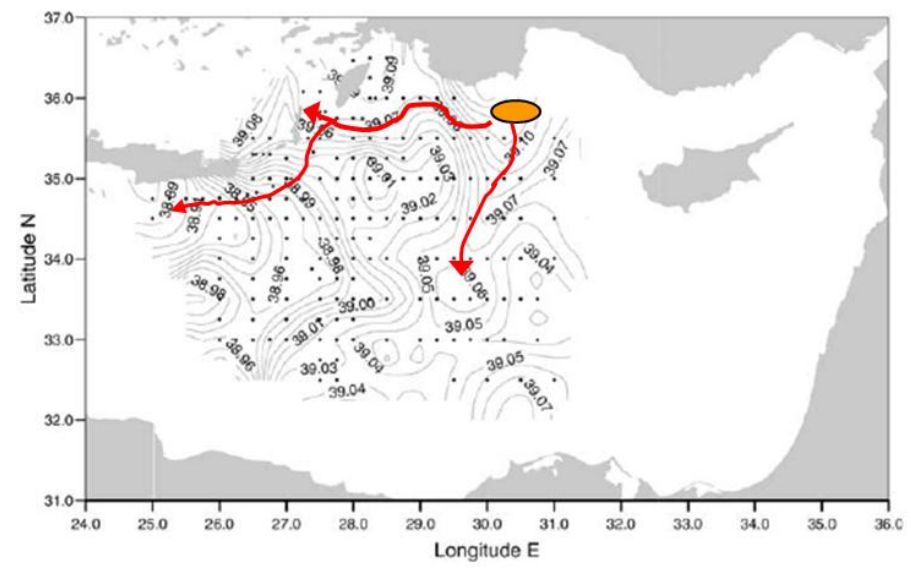

Fig. 4. Salinity at potential density anomaly of $29.0 \mathrm{~kg} \mathrm{~m}^{-3}$ from the LIWEX 1995 cruise. Orange oval indicates the region of LIW formation (Northern Levantine). Red arrows indicate likely pathways based on salinity gradient. Adapted from LIWEX group (2003) (redraw?).

All of these studies suffer from the same thing: the observational data were of limited spatial and temporal extent. and spatial resolution was very low. It is very likely that small and medium scale processes are responsible for the spreading of intermediate water, but were not resolved, or did not occur during the short time of the particular cruise. Further studies have published maps based on model simulations (Wu and Haines 1996; Lascaratos and Nittis 1998) and re-analysis (Pinardi et al. 2015), which solve the problem of resolution and extent, but tend to raise more questions than they answer because of the complex eddy fields and decadal variability revealed. In particular, the model results of $\mathrm{Wu}$ and Haines (1996) provide deep insights into the dispersal of LIW throughout the Mediterranean. They find that the LIW formed in their model (prescribed in the Rhodes Gyre by surface relaxation) breaks up by baroclinic eddies (stratified flow instabilities) which can move eastward against the direction of mean flow. The net effect of the eddies could be to transfer LIW north of Cyprus, southward along the coast of Lebanon and Israel (Plate 3 of Wu and Haines 1996). A mean flow to the west out of the gyre is also seen (as in previous modeling studies that did not resolve eddies such as Haines and Wu (1995)). This branch enters and leaves the Aegean, joining the Ionian basin. Some of this branch also recirculates eastward in the Mersa-Matruh Gyre, and possibly back to the Rhodes Gyre. The idea of mean and time-varying transports was proven to be valuable in Stratford and Williams (1997), who show that tracers released in the Rhodes Gyre simulated by the GCM of $\mathrm{Wu}$ and Haines (1996) not only spread westward into the Aegean under the 
mean flow, but that eddy fluxes were required to account for the flow southward and eastward. This is also described by Lascaratos and Nittis (1998). Additional evidence for LIW pathways can be seen from the 120-year model run of Wu and Haines (1998). By mapping the mean salinity on the LIW density level (28.95) from the last 20 years, it is possible to discern one branch exiting the Aegean and moving into the Ionian, and eventually the Adriatic, while another branch moves south out of the Rhodes Gyre, then west along the southern Mediterranean coast to the Sicily Channel. There is also an indication of a transport of LIW towards the east out of the Rhodes Gyre (Fig. 5).

Model Climatology of Salinity on 28.95 Isopycnal Surface

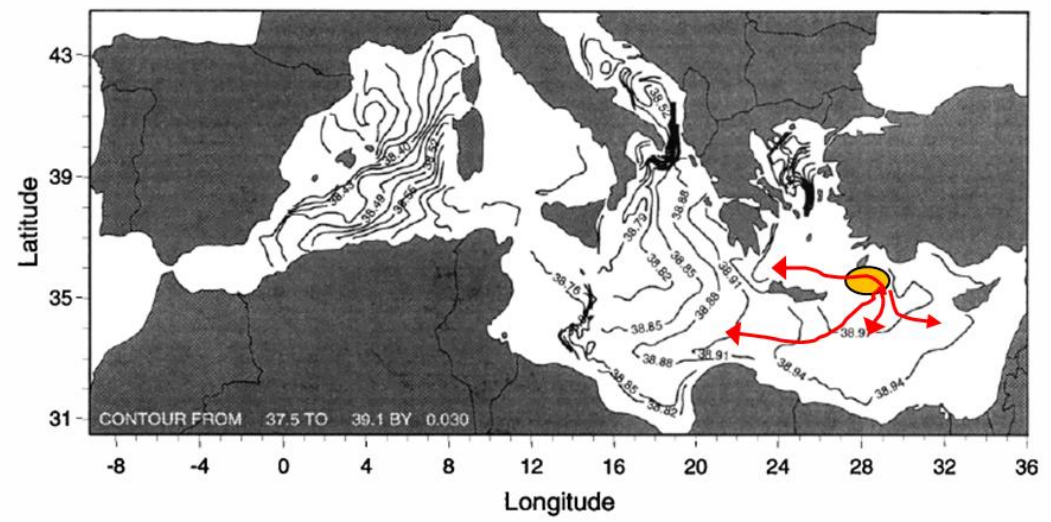

Fig. 5. Salinity on $28.95 \mathrm{~kg} \mathrm{~m}^{-3}$ isopycnal surface from a 20 year average after a 100 -year simulation (adapted from Wu and Haines (1998)). Orange oval indicates the region of LIW formation (Northern Levantine). Red arrows indicate likely pathways based on salinity gradient.(redraw?)

In a recent numerical reanalysis experiment (Pinardi et al. 2015), the intermediate layer circulation $(200-300 \mathrm{~m})$ was computed based on a mean of monthly means over the years 1987-2007 (Fig. 6). However, this can be misleading since actual transport of LIW can occur against the mean flow due to time varying flow (Stratford and Williams 1997). In addition, flow in the ocean more closely moves along density layers, not depth layers. For these reasons, the salinity and currents on the $28.95 \mathrm{~kg} \mathrm{~m}^{-3}$ potential density anomaly surface from the Copernicus Marine Environment Monitoring Service (CMEMS 2017) daily analysis output are also computed here. Averages of instantaneous fields from every 10 days of 2016 show the spreading of LIW in many directions away from the south of Crete (Fig. 6). This is suggested to be the region where LIW was most recently formed as it has the highest salinities. A branch spreading eastward along the Turkish coast is evident, as well as branches encircling Cyprus and the region south of the Rhodes Gyre. In the latter region the LIW seems to encircle a set of three anticyclones. West of Crete the LIW heads straight west into the Ionian, but also with indications of a branch heading northward into the Adriatic, which is not shown by Pinardi et al. (2015). An instantaneous image from 31 January 2016 
indicates the complex transport processes via geostrophic turbulence. It is nearly impossible to track specific parcels without a separate tracer experiment. Even if this were done, it is not clear that the model can adequately simulate the spreading of LIW. Anti-cyclonic eddies with a core of LIW have been observed numerous times with gliders or profiling floats that were not predicted. In some cases, similar features were only present in the re-analysis because of assimilated data. 

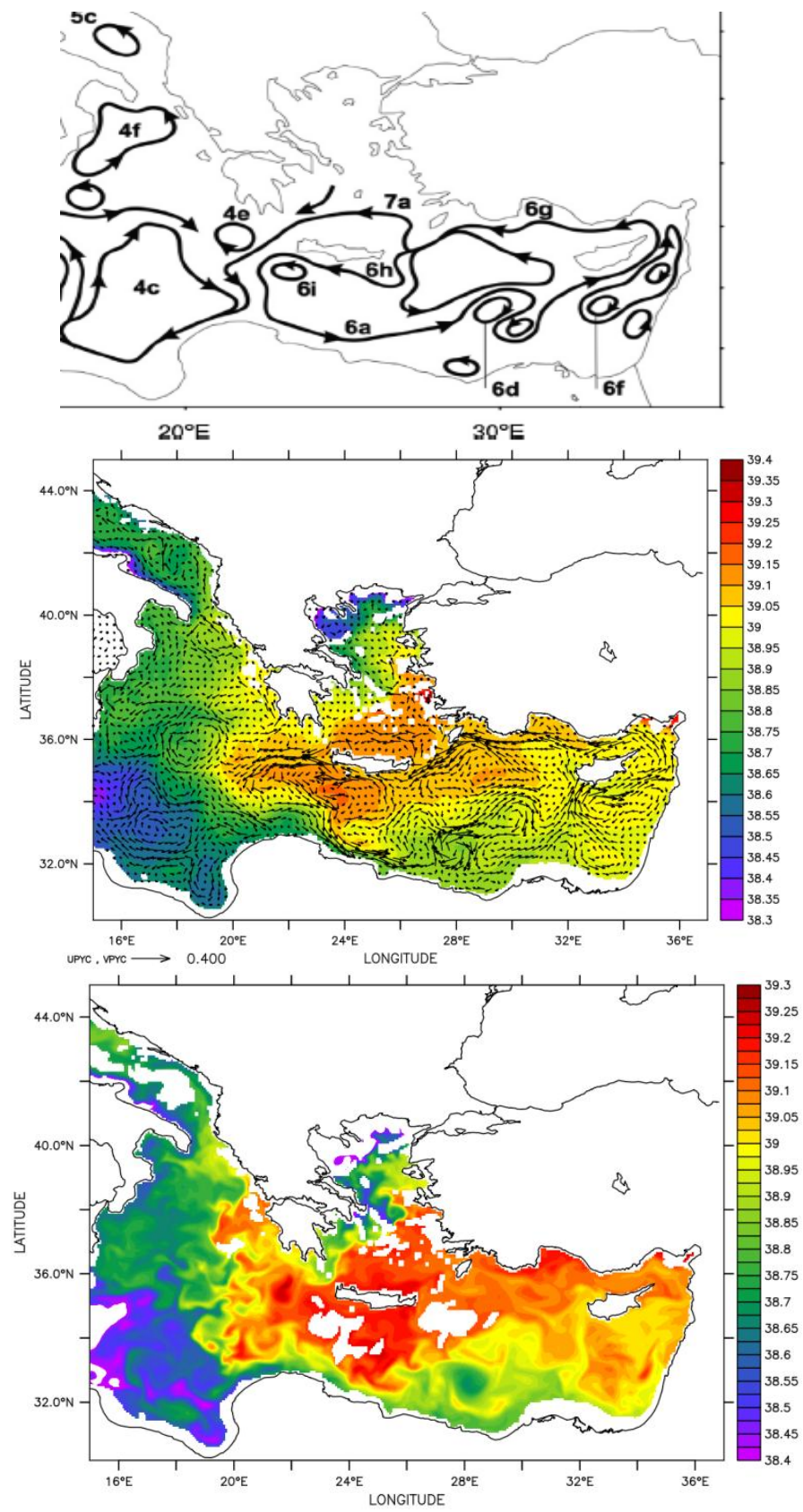

Fig. 6. Top: Eastern Mediterranean circulation from Pinardi et al. (2015). Middle: 2016 average salinity and currents on $28.95 \mathrm{~kg} \mathrm{~m}^{-3} \sigma_{\theta}$ potential density anomaly from CMEMS (2017). Bottom: same for 31 January 2016 instantaneous (white areas are where the isopycnal outcrops). 
It is also noted from other studies that the Adriatic also accepts LIW as a subsurface layer overlaying Adriatic water through the Otranto Channel. Over a few years, LIW, circulating cyclonically in the southern Adriatic, preconditions the area for deep convection and deep water formation that spills back out into the Mediterranean and spreads eastward below existing LIW (Wu and Haines 1996). Pinardi et al. (2015) do not indicate this current in the schematic of the intermediate circulation. Further west, it appears that the Ionian Sea is split from NW to SE by a front in LIW properties. This front generates eddies but is maintained for many years in $\mathrm{Wu}$ and Haines (1996). This would indicate a dynamic barrier to spread of LIW in addition to the topographic one further west at the Sicily Channel, although the latter is likely the rate-limiting one.

By far the most extensive study so far regarding the direct measurement of the intermediate water circulation in the Mediterranean is that of Menna and Poulain (2010), who used profiling floats to describe the currents at $350 \mathrm{~m}$. They found that in the Eastern basin, the flow was primarily along bathymetric contours at mean speeds of about $5 \mathrm{~cm} \mathrm{~s}^{-1}$, except in regions of narrow passages. However, this flow was also dominated by fluctuation, not steady mean flow.

Recent efforts have been made by the authors to map LIW pathways using hydrographic properties measured from profiling floats, gliders and ships. From a map of the depth of the LIW isopycnal from such data over the 2002-2015 period, a picture of spreading and deepening can be seen (Fig. 7). This spreading does not appear to be the same in all directions, but a series of deep/shallow variations are visible around the suspected formation region (Rhodes Gyre). Particularly striking is the depth of LIW in the Cyprus Eddy, south of Cyprus. This multi-lobe dispersion of LIW in depressed isopycnals is consistent with the results of $\mathrm{Wu}$ and Haines (1996) and Stratford and Williams (1997).

A glider mission through the Rhodes Gyre was recently carried out from 23 March to 5 June 2016 (Hayes 2016b). A pattern of 570 profiles crossing the Rhodes Gyre multiple times was carried out, covering the restratification season. After interpolation, it is possible to see a similar lobe-like structure to the LIW surface (Fig. 8) 
16

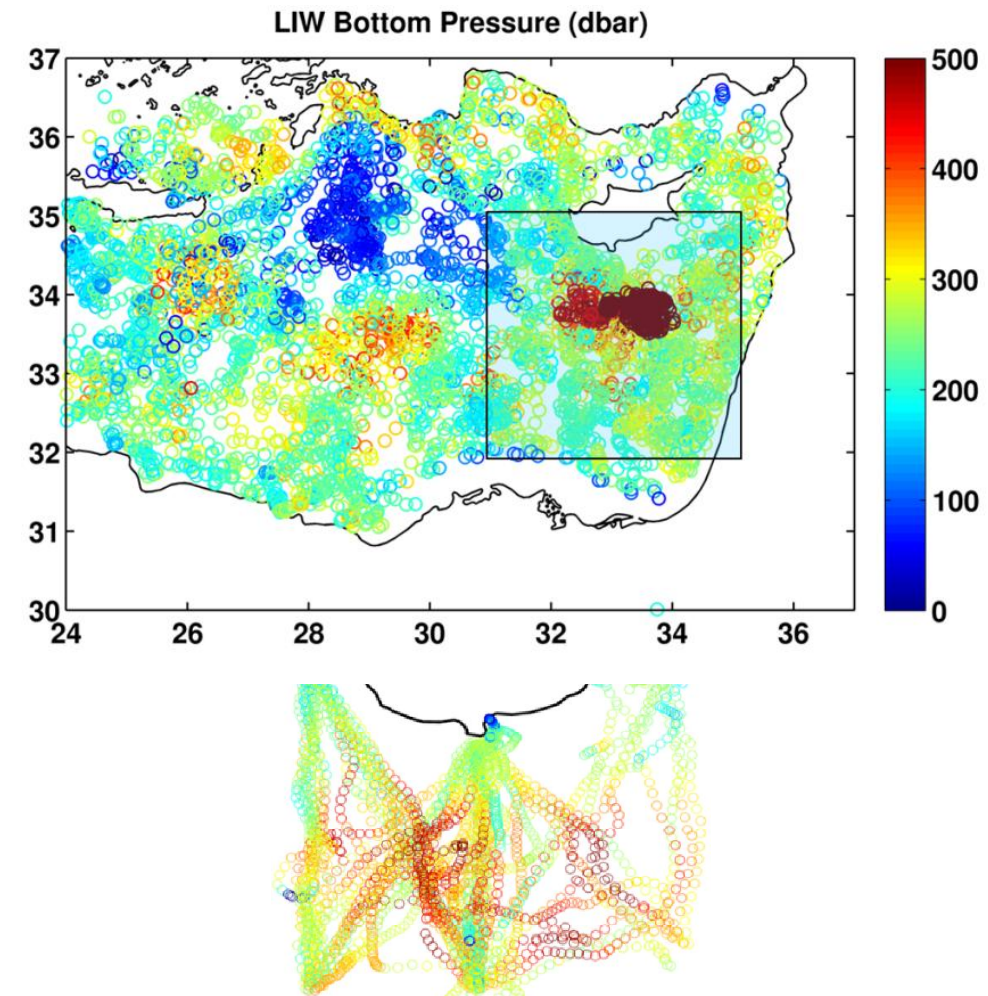

Fig. 7. Map of pressure (dbar) of $29.0 \mathrm{~kg} \mathrm{~m}^{-3}$ isopycnal from Argo floats from 2002 to 2014 , recent years are plotted on top of previous. The box indicates the region included in the time series. Glider results inset for years 2009-2014. (This figure will be redrawn: adding labels, smaller, filled scatter points) 


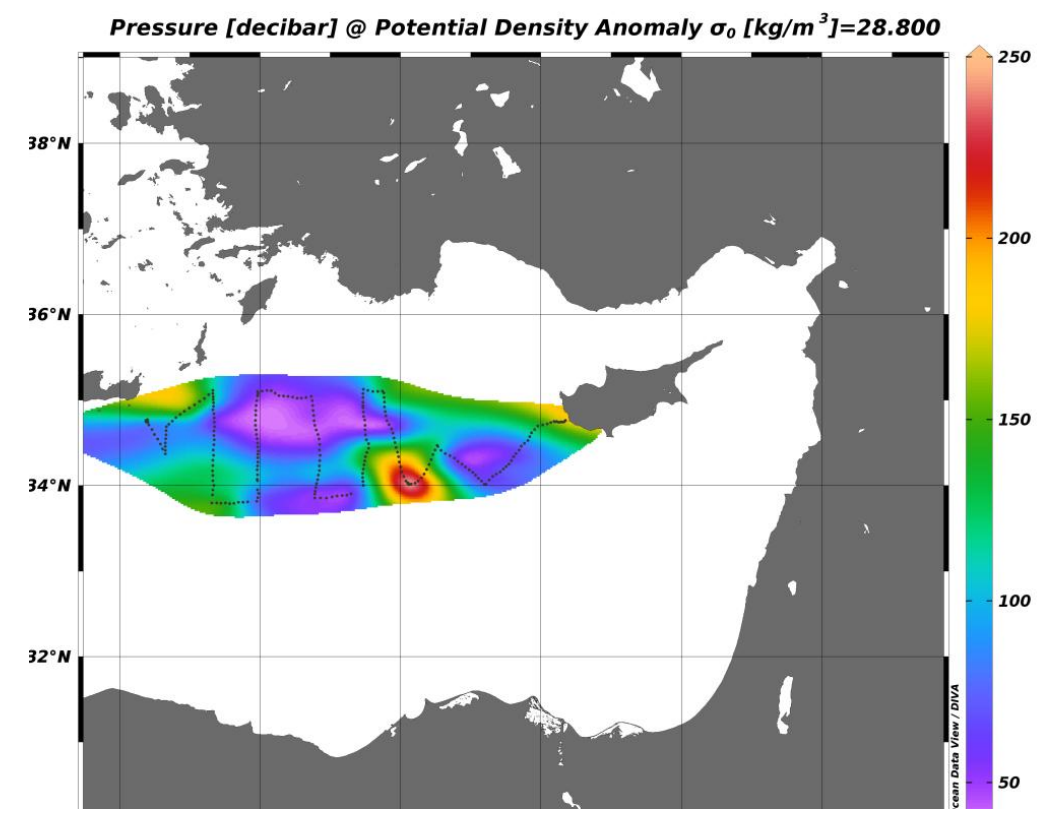

Fig. 8. Depth of isopycnal $28.8 \mathrm{~kg} \mathrm{~m}^{-3}$ during CRELEV-16 glider mission (23 March to 5 June 2016, 570 profiles).

Besides pathways, the properties of intermediate water are important for studies of CWC. In situ data at intermediate depths from ships, floats, moorings and gliders can be used to track the variability of the LIW temperature and salinity. Hydrographic surveys from 1995 to 2012 and recent data from floats and gliders have been used to determine the properties of LIW in the SE Levantine. For glider and float data, the temperature and salinity were extracted and averaged over time and density windows. CYBO data were extracted from 240-260 m depths. This work reveals interannual variability which has yet to be fully explained: a sudden rise in temperature and salinity in 2009, followed by a slow relaxation (Fig. 9). Ozer et al. (2017) also showed the thermohaline trends and decadal fluctuation of intermediate water masses in south eastern Mediterranean (south of $34^{\circ} \mathrm{N}$ and east of $30^{\circ} \mathrm{E}$ ). They found significant positive trends in both temperature and salinity, along with decadal variability of LIW over the years 1979-2014. Prior to this period, and on a longer time scale, there is evidence of long-term increasing trends in the LIW core salinity (Rohling and Bryden 1992; see Skliris this volume) as well as sudden shifts (in the Southeastern Mediterranean (Hecht 1992)). An excellent summary and review of the cross-basin and temporal distribution of nutrients (DIN, TN, DIP, TP, TOC) and oxygen, as well as the carbonate system, is provided by reports for the Marine Strategy Framework Directive on behalf of the Republic of Cyprus (2012). It is shown that the vertically-integrated concentration of nutrients generally decreases from west to east, and at the same time the nutricline deepens. In particular, the phosphocline shows a much more 
dramatic deeping (to over $200 \mathrm{~m}$ ) towards the east. The oxygen minimum zone ranges from about $500 \mathrm{~m}$ to $1000 \mathrm{~m}$ and extends deeper with higher concentrations of oxygen in the eastern as opposed to the western Mediterranean.
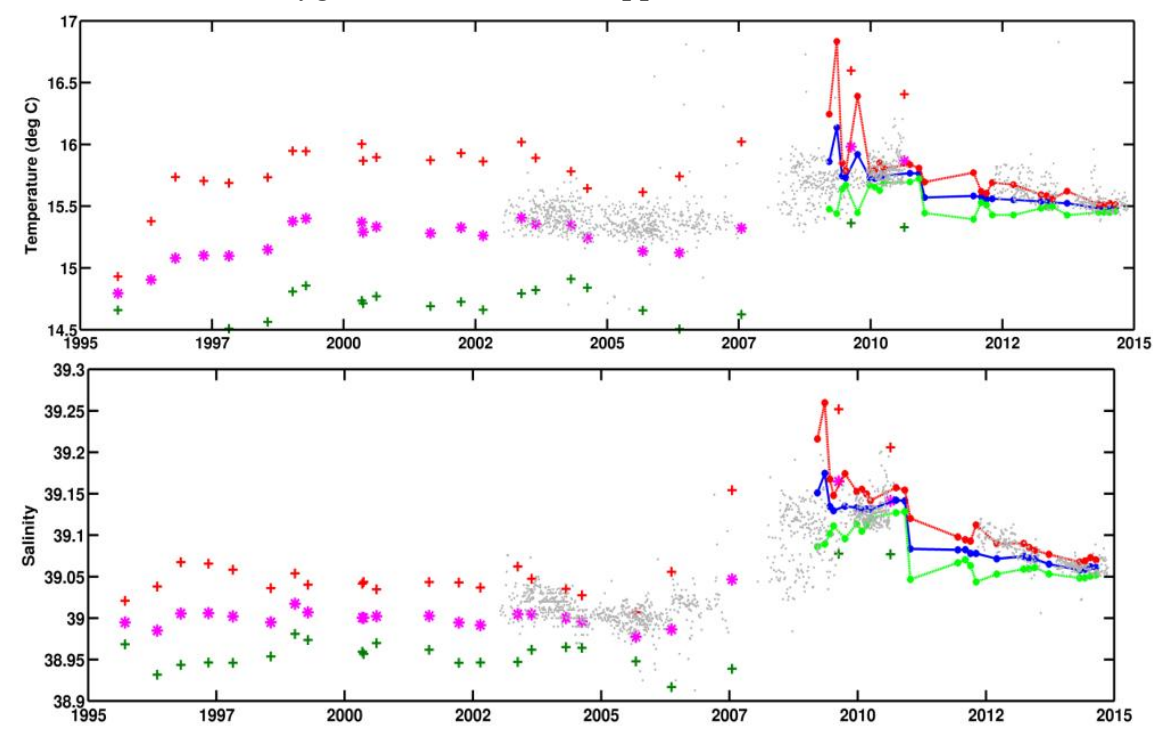

Fig. 9. Time series of (a) salinity and (b) temperature at depth of $29.0 \sigma_{\theta}$ within the box of Fig. 7. Pink: CYBO averages, red/green equal one standard deviation. Connected blue stars: glider monthly averages with one standard deviation. Gray dots are float values (not averaged). (this may be redrawn for better error bar clarity).

Time series measurements at 265 dbar from a mooring near the Eratosthenes Seamount, close to where an isolated CWC sighting occurred (Galil and Zibrowius 1998), show a significant change in temperature (16.3 to 17.2 and back) and salinity (39.21 to 39.36 and back) over the five months of the experiment (Fig. 10). It is surprising to see large excursions in temperature and salinity at this depth, but it indicates that the intermediate water is a dynamic water mass in terms of position in the water column and characteristics, even away from the formation and coastal areas. (The sea depth is approximately $2650 \mathrm{~m}$ in this case.) This is likely because of the various mechanisms and pathways that drive the formation and dispersion of LIW, as well as the decadal variability in the formation of deep waters, which spread into the basin and mix with the LIW the years after its formation.

In summary, intermediate water in the Eastern Mediterranean is exclusively represented by various forms of LIW, possibly from multiple formation origins. LIW spreads throughout the basin at depths of 0 to $500 \mathrm{~m}$ (normally 200-350 m). This lateral spreading via large-scale turbulence seems to be bounded by flow which follows the bathymetric contours cyclonically around the basin. Temperature and salinity vary several tenths of degrees and salinity units (respectively) on scales of hours up to years according to the limited in situ 
observations available. Eventually, LIW exits the Eastern Mediterranean through the Sicily Channel, balancing the inflow of Atlantic Water and the net loss of water through the upper surface (evaporation-precipitation-runoff).
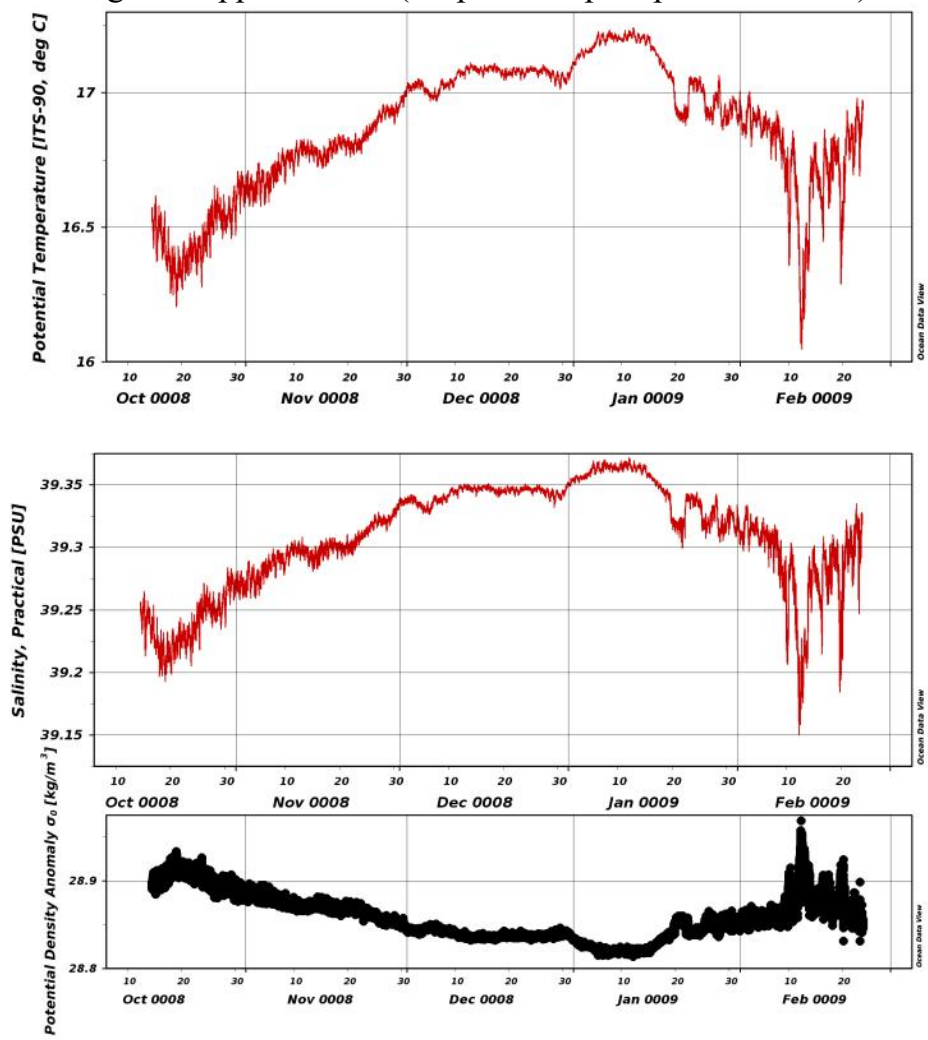

Fig. 10. Temperature, salinity, and potential density from a sensor moored at 265 dbar southwest of Cyprus $\left(\mathrm{N33}^{\circ} \mathrm{53}^{\prime}, \mathrm{E032}^{\circ} \mathrm{11}^{\prime}\right)$, just west of Eratosthenes Seamount. Bottom depth is approximately $2650 \mathrm{~m}$. Data courtesy CSnet, International, Inc. 


\section{Western Mediterranean}

Two types of water of Eastern Mediterranean origin are found in the Sicily Channel: LIW and Aegean and/or Adriatic Deep Water (summarized in Millot 1999). The latter cascades from about $400 \mathrm{~m}$ in the Strait to depths of about 2000 $\mathrm{m}$ in the Tyrrhenian Sea resulting in Tyrrhenian Dense Water (TDW) (Millot 1999). The former, LIW, leaves the Eastern Mediterranean via the Sicily Channel, rounding Sardinia to enter the Western Mediterranean along the periphery of the Tyrrhenian Sea in a cyclonic sense. Properties of the LIW core in the Western Mediterranean are as follows: temperature from 13 to 14.2 , salinity from 38.4 to 38.8, potential density from 29 to 29.10, and depths from 200-600 (Millot 2013). The circulation pattern is summarized in Millot (1999) but with caution that turbulence makes such estimates difficult. Based on hydrographic studies, Millot (1999) concludes that there is a mean current along the west coast of Italy, which diverges at Corsica, with some flow north through the Corsica Channel and some making the loop south then back north around Sardinia first, then as the Western Corsica Current, rejoining downstream of the channel. Once joined, these water masses flow in the Northern Current along the coast of France and Spain. Then, a part flows through the Ibiza Channel (possibly intermittently), while another part flows around Menorca. Some LIW exits at Gibraltar, while some seems to recirculate eastward, but in an unsteady, turbulent way. Modifications to this scheme were noted as instabilities leading to "Leddies" being shed from the southwest corner of Sardinia, meandering and instability of the eastward current along the Algerian coast, and the resulting entrainment of newer LIW coming from the Strait.

An entirely new phenomenon was described by Bosse et al. (2015) in which submesoscale vortices of LIW are generated west of Corsica and Sardinia and populate the basin, significantly influencing the flux of heat and salt from LIW vein to the interior. Normally, LIW is considered to play a critical role for direct influence of the stability of the Gulf of Lions and the strength and timing of the formation of WMDW in wintertime there. Larger scale eddies have been observed previously, Algerian Eddies and Sardinian Eddies, but these were limited to the southern sub-basins (Millot and Taupier-Letage 2005; Testor and Gascard 2005). According to Testor et al. (2005) the Algerian basin appears to be characterized by two cyclonic large-scale circulations, which are mainly barotropic and have been called the Western and Eastern Algerian Gyres.

The salinity and currents on the $28.95 \mathrm{~kg} \mathrm{~m}^{-3}$ potential density anomaly surface from the Copernicus Marine Environment Monitoring Service (CMEMS 2017) daily analysis output for 2016 are plotted for the west in the same way as for the east (Fig. 11). Averages of the instantaneous 10-day output show good agreement with the schematic Pinardi et al. (2015), with the notable exception of a lack of the westward current along the coast of northern Africa in the simulations. The simulations do not show a mean circulation in the Western Algerian gyre as 
expected. As in the eastern basin, instantaneous fields only vaguely resemble the mean field, indicating that time variable transport could play a significant role and calculating transport based on mean currents should be done with caution.

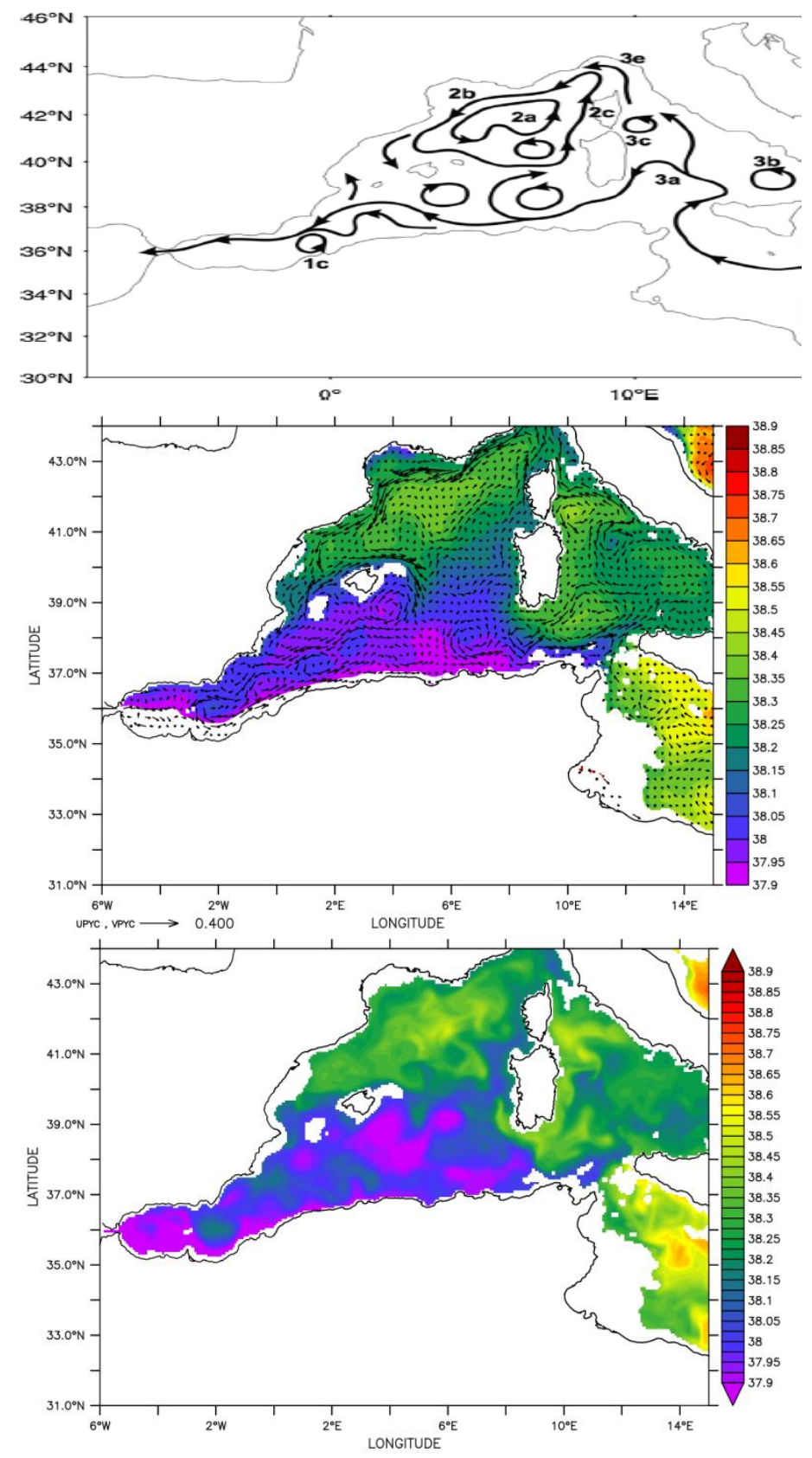


Fig. 11. Top: Western Mediterranean circulation from Pinardi et al. (2015). Middle: 2016 average salinity and currents on $28.95 \mathrm{~kg} \mathrm{~m}^{-3} \sigma_{\theta}$ potential density anomaly from CMEMS (2017). Bottom: same for 21 July 2016 instantaneous (white areas are where the isopycnal outcrops).

Fabri et al (2017) show in their study on the Cassidaigne canyon and using a habitat suitability model that the living conditions of CWC communities can be found in areas of the canyon where the substratum shows irregularities, slopes and topographic highs. Concerning environmental variables temperature and high current velocities (with strong interactions between the canyon and the alongslope Northern Current, and wind-induced upwelling) were identified as explanatory factors of the distribution of CWC. Similar explanations can be probably drawn for the Catalan canyons, which are the only ones that are regularly impacted by cascading of dense shelf water cascading and storm-induced downwellings, and were rocky but also partially sedimented substrates take place. These canyons are also sites with higher fluxes of organic matter deriving from the shelf or frontal zones. Along the Catalan margins, CWCs are found solely in the head of the Lacaze-Duthiers, Cap de Creus, and La Fonera canyons. In general, the spotty presence of CWCs are likely a result of local conditions, since LIW borders all of the northern margins of the Mediterranean.

\section{Summary}

Despite drawbacks associated with the steady-state assumption and the lack of observations, the literature can provide information relevant to the study of CWC, even if crude. For example, progress can be made on understanding pathways of larval spread, and the connection to potential changes in the deep water formation and spreading processes using ocean re-analyses and operational forecasts (CMEMS 2017). As mentioned in Evans et al. (see this volume), thriving CWC assemblages occur in the Mediterranean, distributed along the circulation path of the Levantine Intermediate Water, which appears to be a main driver for CWC distribution in the Mediterranean (Taviani et al. 2011). As the observing system improves, and as the scientific community is able to leverage focused programs on new and existing areas, this cross-basin picture will have to be revised.

Acknowledgments Thanks to the reviewers who have pointed out ways to improve this manuscript. 


\section{References}

Bensi M., Cardin V., Rubino A., Notarstefano G., and Poulain P.-M. (2013). Effects of winter convection on the deep layer of the Southern Adriatic Sea in 2012. Journal of Geophysical Research: Oceans, Vol. 118, 1-12, doi:10.1002/2013JC009432

Borzelli, G. L. E., M. Gačić, V. Cardin, and G. Civitarese (2009), Eastern Mediterranean Transient and reversal of the Ionian Sea circulation, Geophys. Res. Lett., 36, L15108, doi:10.1029/2009GL039261.

Bosse, A., Testor, P., Mortier, L., Prieur, L., Taillandier, V., d'Ortenzio, F., Coppola, L. (2015). Spreading of Levantine Intermediate Waters by submesoscale coherent vortices in the northwestern Mediterranean Sea as observed with gliders. Journal of Geophysical Research: Oceans, 120(3), 1599-1622.

Bosse, A., Testor, P., Houpert, L., Damien, P., Prieur, L., Hayes, D., ... \& Karstensen, J. (2016). Scales and dynamics of Submesoscale Coherent Vortices formed by deep convection in the northwestern Mediterranean Sea. Journal of Geophysical Research: Oceans, 121(10), 77167742.

Brenner, S., Z. Rosentraub, J. Bishop, M. Krom, The mixed layer/thermocline cycle of a persistent warm core eddy in the eastern Mediterranean, Dyn. Atmos. Oceans, 15, 455-476, 1991.

Canals, M., Puig, P., Durrieu-de-Madron, X., Heussner, S., Palanques, A., Fabres, J., 2006. Flushing submarine canyons. Nature 444, 347-354. doi: 10.1038/nature05271.

CMEMS, 2017

Durrieu de Madron, X., Zervakis, V., Theocharis, A., Georgopoulos, D., 2005. Comments on "Cascades of dense water around the world ocean". Prog. Oceanogr. 64, 83-90.

Durrieu de Madron, X., Houpert, L., Puig, P., Sanchez-Vidal, A., Testor, P., Bosse, A., Estournel, C., Somot, S., Bourrin, F., Bouin, M.N. and Beauverger, M., 2013. Interaction of dense shelf water cascading and open-sea convection in the northwestern Mediterranean during winter 2012. Geophysical Research Letters, 40(7), pp.1379-1385.

EMODnet - European Marine Observation and Data Network. 2017. Internet website: http://www.emodnet-bathymetry.eu/.

Evans et al., this volume.

Fabri M-C., A. Bargain, I. Pairaud, L. Pedel, I. Taupier-Letage, Cold-water coral ecosystems in Cassidaigne Canyon: An assessment of their environmental living conditions. Deep Sea Research Part II: Topical Studies in Oceanography, 137, 2017

Gačić, M., Borzelli, G.L.E., Civitarese, G., Cardin, V., Yari, S., 2010. Can internal processes sustain reversals of the ocean upper circulation? The Ionian Sea example. Geophys. Res. Lett. 37, L09608. doi: 10.1029/2010gl043216.

Gačić, M., G. Civitarese, G. L. Eusebi Borzelli, V. Kovačević, P.-M. Poulain, A. Theocharis, M. Menna, A. Catucci, and N. Zarokanellos (2011), On the relationship between the decadal oscillations of the northern Ionian Sea and the salinity distributions in the eastern Mediterranean, J. Geophys. Res., 116, C12002, doi:10.1029/2011JC007280.

Galil, B. \& Zibrowius, H. Senckenbergiana maritima (1998) 28: 111. https://doi.org/10.1007/BF03043142

Gerges MA., 1977. A numerical investigation of the circulation in the Mediterranean Sea, Rapp. Comm. Inter. Mer Médit., 24, 25-30.

Haines K, Wu Pl (1995). A modelling study of the thermohaline circulation of the Mediterranean Sea: Water formation and dispersal. Oceanologica Acta, 18(4), 401-417. Open Access version : http://archimer.ifremer.fr/doc/00323/43387/

Hayes, D. R., H. Gildor, A. Bosse, L. Mortier and P. Royer-Gaspard, 2016a, "On the evolution of the long-lived subsurface mesoscale eddy south of Cyprus," Rapp. Comm. int. Mer Médit., 41.

Hayes, D.R., 2016b, "Physical oceanography from eight Seaglider missions in the Mediterranean Sea, Eastern Basin" doi:10.1594/PANGAEA.860867 
Hecht, A., N. Pinardi, and A.R. Robinson, 1988: Currents, Water Masses, Eddies and Jets in the Mediterranean Levantine Basin. J. Phys. Oceanogr., 18, 1320-1353, https://doi.org/10.1175/1520-0485(1988)018<1320:CWMEAJ >2.0.CO;2

Hecht, A., 1992. Abrupt changes in the characteristics of Atlantic and Levantine intermediate waters in the Southeastern Levantine basin. Oceanologica Acta 15, 25-42.

Houpert, L., Durrieu de Madron, X., Testor, P., Bosse, A., D'Ortenzio, F., Bouin, M. N., ... \& Coppola, L. (2016). Observations of open-ocean deep convection in the northwestern Mediterranean Sea: Seasonal and interannual variability of mixing and deep water masses for the 2007-2013 Period. Journal of Geophysical Research: Oceans, 121(11), 8139-8171.

Lacombe, H., P. Tchernia, Quelques traits generaux de l'Hydrologie Mediterrane, Cah. Oceanogr., 12, 527-547, 1960.

Lascaratos, A. (1993). Estimation of deep and intermediate water mass formation rates in the Mediterranean Sea. Deep Sea Research Part II: Topical Studies in Oceanography, 40(6), 1327-1332.

Lascaratos, A., R. G. Williams, and E. Tragou (1993), A mixed-layer study of the formation of Levantine intermediate water, J. Geophys. Res., 98(C8), 14739-14749, doi:10.1029/93JC00912.

Lascaratos, A., and K. Nittis. "A High-resolution Three-dimensional Numerical Study of Intermediate Water Formation in the Levantine Sea." J. Geophys. Res. 103, no. C9 (1998).

The LIWEX Group (2003), The Levantine Intermediate Water Experiment (LIWEX) Group: Levantine basin-A laboratory for multiple water mass formation processes, J. Geophys. Res., 108, 8101, doi:10.1029/2002JC001643, C9.

Malanotte-Rizzoli, P. and Hecht, A. 1988. Large-scale properties of the eastern Mediterranean: A review. Oceanologica Acta, 11: 323-335.

Malanotte-Rizzoli, P., Artale, V., Borzelli-Eusebi, G.L., Brenner, S., Crise, A., Gacic, M., Kress, N., Marullo, S., d'Alcalà, M.R., Sofianos, S. and Tanhua, T., 2014. Physical forcing and physical/biochemical variability of the Mediterranean Sea: a review of unresolved issues and directions for future research. Ocean Science, 10(3), p.281.

Menna, M., P.-M. Poulain, G. Zodiatis and I. Gertman (2012) On the surface circulation of the Levantine sub-basin derived from Lagrangian drifters and satellite altimetry data. Deep-Sea Research I, 65, 46-58. doi: 10.1016/j.dsr.2012.02.008.

Menna, M, \& Poulain, PM 2010, 'Mediterranean intermediate circulation estimated from Argo data in 2003--2010', Ocean Science, vol. 6, no. 1, pp. 331-343.

Millot, C., 1999. Circulation in the western Mediterranean Sea. Journal of Marine Systems, 20(1), pp.423-442.

Millot, C. 2013 Levantine Intermediate Water characteristics : an astounding general misunderstanding ! Scientia Marina, 77(2), 217-232.

Millot, C., \& Taupier-Letage, I. (2005). Circulation in the Mediterranean sea. The Mediterranean Sea, 323-334.

Morcos, S.A. Sources of Mediterranean Intermediate Water in the Levantine Sea, A.L. Gordon (Ed.), Studies in Physical Oceanography: a Tribute to G. Wüst on his 80th Birthday, Gordon and Breach, New York (1972), pp. 185-206

Nielsen, J. N., Hydrography of the Mediterranean and adjacent waters, Rep. Dan. Oceanogr. Exped. Mediter., 1, 77-192, 1912.

Nittis, K., Lascaratos, A, 1998. Diagnostic and prognostic numerical studies of LIW formation.J. Mar. Syst. 18, 179-195.

Ovchinnikov, I. M., 1966. Circulation in the surface and intermediate layers of the Mediterranean. Oceanology, 6, 49-59.

Ovchinnikov, I.M. The Formation of Intermediate Water in the Mediterranean Oceanology, 24 (1984), pp. 168-173.

Ozer, T., Gertman, I., Kress, N., Silverman, J. and Herut, B., 2017. Interannual thermohaline (1979-2014) and nutrient (2002-2014) dynamics in the Levantine surface and intermediate water masses, SE Mediterranean Sea. Global and Planetary Change, 151, pp.60-67. 
Özsoy, E., A. Hecht, U. Unluata, Circulation and hydrography of the Levantine Basin: Results of POEM coordinated experiments 1985/1986, Prog. Oceanogr., 1989.

Özsoy, E., A. Hecht, U. Unluata, S. Brenner, T. Oguz, J. Bishop, M.A. Latif, and Z. Rozentraub.1991. A review of the Levantine Basin circulation and variability during 19851988. Dynamics of Atmospheres and Oceans 15:421-456.

Özsoy, E. et al, 1993. A synthesis of the Levantine Basin circulation and hydrography, 19851990

Ozturgut, E. (1976) The Source and Spreading of the Levantine Intermediate Water in the Eastern Mediterranean, Saclant ASW Research Centre Memorandum SM-92, La Spezia, Italy, $45 \mathrm{pp}$.

Pinardi, N., Zavatarelli, M., Adani, M., Coppini, G., Fratianni, C., Oddo, P., ... \& Bonaduce, A. (2015). Mediterranean Sea large-scale low-frequency ocean variability and water mass formation rates from 1987 to 2007: a retrospective analysis. Progress in Oceanography, 132, 318-332.

Poulain, P.-M., M. Menna and E. Mauri (2012) Surface geostrophic circulation of the Mediterranean Sea derived from drifter and satellite altimeter data. Journal of Physical Oceanography, 42, 973-990.

Republic of Cyprus, Ministry of Agriculture, Natural Resources, and the Environment Department of Fisheries and Marine Research 2012 Initial Assessment of the Marine Environment of Cyprus Part I - Characteristics web link accessed 20170925: http://cdr.eionet.europa.eu/cy/eu/msfd8910/msfd4text/envufw40q/1Initial Assesment Report.pdf/manage document.

Raineault N.A., P.A. Ramey-Balci, T.M. Shank, E.K. Bors, Duman M., Ürkmez D., \& S. Tüzün (2013) Exploration of the Anaximander Mountains: Mud Volcanoes, Cold-Seep Communities, and Cold water Corals. Oceanography 26(1) supplement: 30-35.

Rohling, E. J., and H. L. Bryden (1992), Man-induced salinity and temperature increases in western Mediterranean deep water, J. Geophys. Res., 97(C7), 11191-11198, doi:10.1029/92JC00767.

Rio M.-H., Pascual A., Poulain P.-M., Menna M., Barcelò B. and Tintorè J. (2014) Computation of a new mean dynamic topography for the Mediterranean Sea from model outputs, altimeter measurements and oceanographic in situ data. Ocean Sci., doi:10.5194/os-10-731-2014.

Roether, W., Klein, B., Manca, B.B., Theocharis, A. and Kioroglou, S., 2007. Transient Eastern Mediterranean deep waters in response to the massive dense-water output of the Aegean Sea in the 1990s. Progress in Oceanography, 74(4), pp.540-571.

Schroeder, K., S. A. Josey, M. Herrmann, L. Grignon, G. P. Gasparini, and H. L. Bryden. "Abrupt Warming and Salting of the Western Mediterranean Deep Water after 2005: Atmospheric Forcings and Lateral Advection.” J Geophys Res: Oceans 115, no. C8 (2010).

Schroeder, this volume. Recent changes in the Mediterranean deep-water circulation (episodes during the 1980s and 1990s)

Schroeder, K, Jesus Garcìa-Lafuente, Simon A. Josey, Vincenzo Artale, Bruno Buongiorno Nardelli, Adriana Carrillo, Miroslav Gačić, Gian Pietro Gasparini, Marine Herrmann, Piero Lionello, Wolfgang Ludwig, Claude Millot, Emin Özsoy, Giovanna Pisacane, Jose C. Sánchez-Garrido, Gianmaria Sannino, Rosalia Santoleri, Samuel Somot, Mariavittoria Struglia, Emil Stanev, Isabelle Taupier-Letage, Michael N. Tsimplis, Manuel Vargas-Yáñez, Vassilis Zervakis, George Zodiatis, "Circulation of the Mediterranean Sea and its Variability", in The Climate of the Mediterranean Region, 2012, 187. Ed. P. Lionelo.

Shank, T.M., S. Herrera, W. Cho, C. Roman, and K. Croff Bell. 2011. Exploration of the Anaximander mud volcanoes. Pp. 22-23 in New Frontiers in Ocean Exploration: The E/V Nautilus 2010 Field Season. K.L.C. Bell and S. Fuller, eds, Oceanography 24(1), supplement, http://dx.doi.org/10.5670/oceanog.24.1.supplement.

Skliris, N. this volume.

Skliris, N. (2014). Past, present and future patterns of the thermohaline circulation and characteristic water masses of the Mediterranean Sea. In The Mediterranean Sea (pp. 29-48). Springer Netherlands. 
Skliris, A. Lascaratos Impacts of the Nile River damming on the thermohaline circulation and water mass characteristics of the Mediterranean Sea J. Mar. Syst., 52 (2004), pp. 121-143.

Sofianos, this volume. Perspectives of modelling with implications on water circulation.

Stratford, K., and R. G. Williams (1997), A tracer study of the formation, dispersal, and renewal of Levantine Intermediate Water, J. Geophys. Res., 102(C6), 12539-12549, doi:10.1029/97JC00019.

Sur, H. I., E. Özsoy, U. Unluata, Simultaneous deep and intermediate convection in the northern Levantine Sea, winter 1992, Oceanol. Acta, 16, 33-43, 1992.

Tanhua, T et al. (2013): Repeat hydrography in the Mediterranean Sea, data from the Meteor cruise 84/3 in 2011. Earth System Science Data, 5(2), 289-294, https://doi.org/10.5194/essd5-289-2013.

Taviani, M., L. Angeletti, B. Antolini, A. Ceregato, C. Froglia, M. Lopez Correa, P. Montagna, A. Remia, F. Trincardi, and A. Vertino. "Geo-biology of Mediterranean deep-water coral ecosystems." Marine Research at CNR 6 (2011): 705-719.

Testor, P. and Gascard, J.C., 2005. Large scale flow separation and mesoscale eddy formation in the Algerian Basin. Progress in Oceanography, 66(2), pp.211-230.

Testor, P., U. Send, J.-C. Gascard, C. Millot, I. Taupier-Letage, and K. Béranger (2005), The mean circulation of the southwestern Mediterranean Sea: Algerian Gyres, J. Geophys. Res., 110, C11017, doi:10.1029/2004JC002861.

Theocharis, A., Nittis, K., Kontoyiannis, H., Papageorgiou, E. and Balopoulos, E., 1999. Climatic changes in the Aegean Sea influence the Eastern Mediterranean thermohaline circulation (1986-1997). Geophysical Research Letters, 26(11), pp.1617-1620.

Tsimplis, M. N., \& Bryden, H. L. (2000). Estimation of the transports through the Strait of Gibraltar. Deep Sea Research Part I: Oceanographic Research Papers, 47(12), 2219-2242.

Tsimplis, M.N., Zervakis, V., Josey, S.A., Peneva, E.L., Struglia, M.V., Stanev, E.V., Theocharis, A., Lionello, P., Malanotte-Rizzoli, P., Artale, V. and Tragou, E., 2006. Changes in the oceanography of the Mediterranean Sea and their link to climate variability. Developments in Earth and Environmental Sciences, 4, pp.227-282.

$\mathrm{Wu}, \mathrm{P}$., and K. Haines (1996), Modeling the dispersal of Levantine Intermediate Water and its role in Mediterranean deep water formation, J. Geophys. Res., 101(C3), 6591-6607, doi:10.1029/95JC03555.

Wu, P., and K. Haines. "The General Circulation of the Mediterranean Sea from a 100-year Simulation." J Geophys Res: Oceans 103, no. C1 (1998).

Wüst, G. (1961), On the vertical circulation of the Mediterranean Sea, J. Geophys. Res., 66(10), 3261-3271, doi:10.1029/JZ066i010p03261. 